\title{
criterns
}

The Anatonyy of two Undescribed

Species of Helodrilus from Illinois

Zoology

M. S.

1914

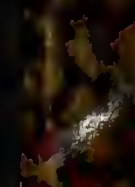



Digitized by the Internet Archive in 2013

http://archive.org/details/anatomyoftwounde00gitt 


\section{THE ANATOMY OF TWO UNDESCRIBED SPECIES OF HELODRILUS FROM ILLINOIS}

BY

\section{ELIZABETH MAE GITTINS}

S. B. Drake University, 1909

\section{THESIS}

Submitted in Partial Fulfillment of the Requirements for the Degree of

MASTER OF SCIENCE

IN ZOOLOGY

IN

THE GRADUATE SCHOOL

OF THE

UNIVERSITY OF ILLINOIS

1914 



\section{UNIVERSITY OF ILLINOIS \\ THE GRADUATE SCHOOL}

JUNE $\quad 6 \quad 1914 \quad 190$

I HEREBY RECOMMEND THAT THE THESIS PREPARED UNDER MY SUPERVISION BY

\section{ELIZABETH MAE GITTINS}

ENTITLED THE ANATOMY OF TWO UNDESCRIBED SPECIES OF

\section{HELODRILUS FROM ILLINOIS}

BE ACCEPTED AS FULFILling THIS PART OF THE REQUiREMENTS FOR THE

DEGREE OF

MASTER OF SCIENCE

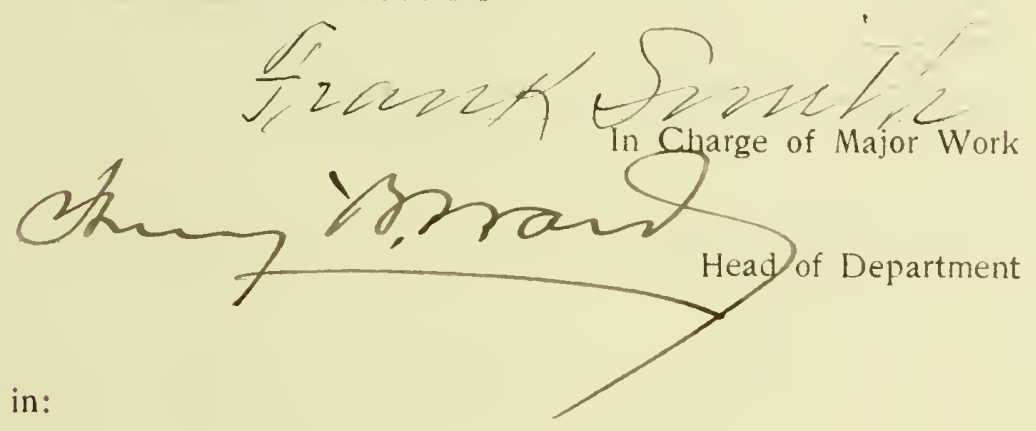

Recommendation concurred in:

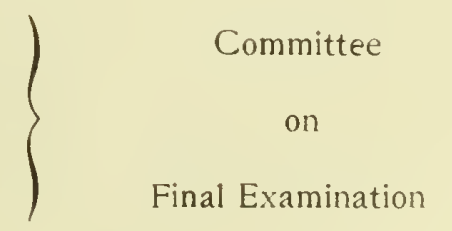


$\Leftrightarrow$ 
CONTENTS.

I. Introductory

II. Helodrilus (Bimastus) zeteki n. sp.

1. Definition

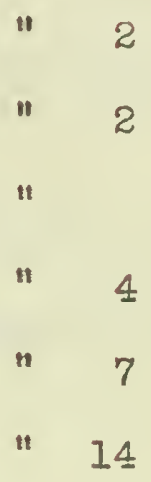

4. Affinities.

a. External

b. Internal

- Habitat

3. Anatomy

III. Helodrilus (Bimastus) longicinctus n. sp.

1. Definition

2. Habitat

3. Anatomy
a. External
b. Internal

4. Affinities

IV. Definition of Genus Helodrilus

V. Definition of Subgenus Bimastus

VI. Literature Cited.

VII. Explanation of Plates

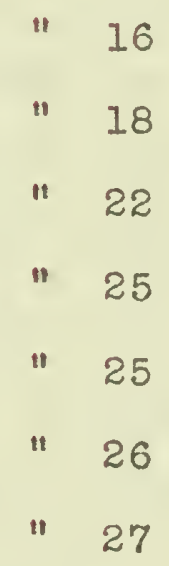



THE ANATOMY OF TWO UNDESCRIBED SPECIES OF HELODRILUS

FROM ILLINOIS.

The investigation which forms the basis of this thesis, was made on specimens from the collections of Professor Frank

Smith. This material consists of specimens, preserved entire, and of transverse and longitudinal serial sections.

The writer wishes to express her indebtedness to Professor Smith, who has had supervision of her work, for suggestions and the use of literature.

\section{Helodrilus(Bimastus) zeteki n. sp.}

(Plate I, Figs. 1, 3, 4, 7 Plate II, Figs. 8, 13) DEFINITION.

Color of living worm, bright chestnut, tinged with purple, more pronounced anteriorly. Length extended, 97 - $140 \mathrm{~mm}$. Maximum diameter $5-6 \frac{1}{2} \mathrm{~mm}$. at the clitellum. Somites 100 - 142 .

Prostomium epilobic $1 / 3-1 / 2$. Setae closely paired. Anterior to the clitellum $\underline{\mathrm{aa}}: \underline{\mathrm{ab}}: \underline{\mathrm{bc}}: \underline{\mathrm{cd}}: \underline{\mathrm{dd}}=125: 19: 100: 19: 400$. Posterior to the clitellum bc is relatively greater, and dd is somewhat less than one-half the circumference. First doesal pore V/VI. Clitellum XXVII - XXXVII(= Il somites); incomplete ventraI1y. Tubercula pubertatis lacking. Spermiducal pores on XV inconspicuous, with the glandular tissue encroaching but slightly on XVI. Septa $\overline{\overline{\text { IIVII }}}-\overline{\overline{\text { XII/XIII }}} ; \overline{\overline{\text { XIII/XIV }}}-\overline{\overline{\overline{X I V} / X V}}$. Sperm sacs, two pairs in XI and XII. Spermathecae lacking.

The description of this species is based on specimens found in the woodlands of two localities, Urbana, Illinois and Cheboygan County, Michigan, near Douglas Lake. The earthworms from Urbana 

were collected by Mr. James Zetek, three or four miles northeast of the city in the Cottonwood and Brownfield moods, which are tracts of orifinal forest. The specimens from Michigan were collected by Miss Bessie Green.

These earthworms live in the wood or under the bark of decaying logs.

A specimen, from the Zetek collection from Cottonwood Woods, was selected as the type. Reference to the paratypes is made as follows :
A - specimens from Brownfield Woods
B - " " shore of Douglas Lake (Grape Vine Point)
C - single specimen from shore of Douglas Lake (near Maple River outlet) 



\section{EXTERNAL CHARACTERS}

The color of the dorsal surface of the living worn is bright chestnut, tinged with purple, and is more pronounced in the anterior part of the body. The ventral surface is brownish gray; the clitel Ium golden brown.

The length is $97-140 \mathrm{~mm}$; the maximum diameter is $5-6 \frac{1}{2}$ mm. The measurements of the type specimen and of the paratypes are as follows:

Type specimen - Length $135 \mathrm{~mm}$; maximum diameter $6 \mathrm{~mm}$.

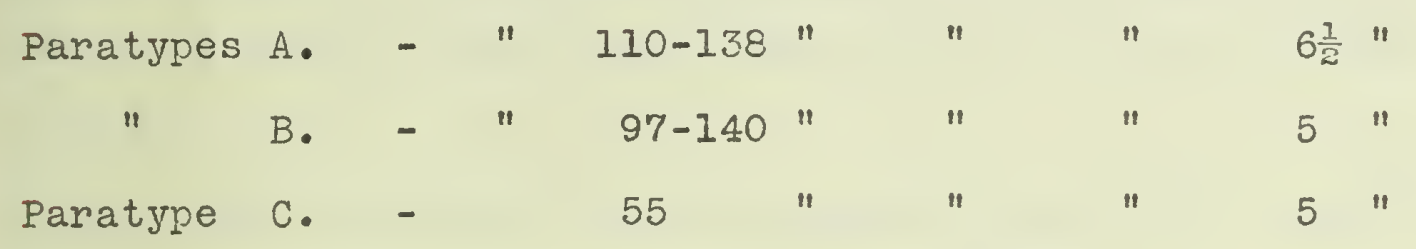

Paratype $\mathrm{C}$. is abnormally short, having apparently regenerated a posterior end. The specimens from Michigan, paratypes $B$ and $\mathrm{C}$, are generally smaller than those from Illinois.

The body is slightly flattened ventrally and of nearly the same diameter throughout its length. The anterior end tapers from XII or XIII to I, which in the extended worm has an approximate diameter of only $3 \mathrm{~mm}$. The posterior half of the pre-clitellar region, in the type specimen $5 \mathrm{~mm}$. In diameter, is the thickest part of the body excepting the clitellum which measures $6 \mathrm{~mm}$. Posterior to the clitellum the diameter is nearly uniform and about $4 \mathrm{mr}$. In the living worm this region is slightly flattened and there are distinct dorso-lateral and ventro-lateral angles.

The number of somites in the paratypes is $134-142$. There are just 100 in the body of the type specimen. Those anterior to the olitellum are slightly longer and more distinct than the posterior ones. The prostomium is epilobic $1 / 3-1 / 2$ (Fig 1 ). 

The setae are closely paired and the rows are nearly paral1e1. In XXIV $\underline{\mathrm{aa}}: \underline{\mathrm{ab}}: \underline{\mathrm{bc}}: \underline{\mathrm{cd}}: \underline{\mathrm{dd}}=125: 19: 100: 19: 400$. and $\underline{d d}=$ approximately one-half the circumference.

Posterior to the clitellum bc is relatively great and $\underline{d d}$ is somewhat less than one half the circumference.

The first dorsal pore is in the inter-segmental groove $\mathrm{V} / \mathrm{VI}$ and is smaller than the following ones.

The clitellum is on XXVII - XXXVII( = 11 somites); in the type specimen not as well developed on XXVII as on the other somites. One specimen paratype A has the clitellum on $\frac{1}{2}$ XXVII XXXVIII.

The clitellum is saddle-shaped and reaches its most ventral limit on XXXIV, where the margins are only $11 / 3-11 / 2 \mathrm{~mm}$. apart. On XXVII and XXVIII the ventral margin is slightly dorsal to $\underline{\mathrm{b}}$; on XXIX between $\underline{\mathrm{a}}$ and $\underline{\mathrm{b}}$; and on XXX - XXXVI includes the ventral setae. The posterio-ventral margins of the clitellum are abrupt, and do not extend as far ventrally as $\underline{b}$. Tubercula pubertatis are lacking.

The crescent shaped mouth on the ventral part of I is overhung by the prostomium. The anus is a vertical slit-like aperture on the last somite.

Paired spermiducal pores are on XV, dorsal to $\underline{b}$; the interval between being about one fifth bc. Each is in a rather deep transverse groove, bordered by slightly elevated glandular tissue which reaches ventrally to $\underline{b}$, anteriorly as far as XIV/XV; and posteriorly encroaches on XVI. The oviducal pores are small, round or oval apertures on XIV, immediately dorsal to $\underline{b}$. The nephridiospores may have either of two possible posi- 

tions. They may have a ventral position slightly dorsal to $\underline{b}$ or a more dorsal one which is approximately half way between $\underline{\mathrm{d}}$ and the mid-dorsal line. The nephridiozpores form nearly straight rows. Anterior to the clitellum the two rows of dorsally placed nephridio -pores are not as straight as they are posterior to the clitellum. The ventral rows are dorsal to $\underline{\mathrm{b}}$; the interval between being equal to about two ab. The dorsal rows anterior to the clitellum are mid-way between line $\underline{d}$ and the mid-Corsal line; posterior to the clitellum they are much nearer line d than to the mid-dorsal line. Each nephridiopore is in the anterior part of the somite, near the inter-segmental groove. In the type specimen these pores are large and distinct and are easily seen without a lens. 



\section{INTERITAI CHARACTERS}

CENTRAL NERVOUS SYSTEY.

The supra-oesophageal ganglion or brain, dorgal to the pharynx in III and the sub-oesophageal ganglion ventral to the pharynx in IV are connected by the circum-oesophageal connectives. The ventral nerve cord extends posteriorly, from the sub-oesophageal ganglion, to the end of the body. In each somite poterior to IV there is an enlargement of the cord, forming a ganglionic mass.

Two pairs of nerves are given off from the circum-oesophageal connectives in IV; the first innervatirg the buccal region, and the second the ventral body wall. The nerve cord has three pairs of branches in each somite of the body posterior to IV. The first pair is about one fourth, and the third pair about three fourths of the length of the somite from the anterior septum. The second pair arises a little anterior to the third.

ALINENTARY CANAL.

The specialized region of the alimentary canal are similar to those ir Lumbricus terrestris.

The buccal region in I and II is thin-walled because the circular and longitudinal mucle layers are each much reduced. Columnar epithelial cells line the cavity. The pharynx is in III and IV. Its dorsal and laterel walls are much thickened by the addition of mucular and glandular tissue. (Fig.8.). The latter is developed chiefly as dorso-lateral masses which increase gradually in size from the anterior to the posterior end, where they are large, and Where they meet in the mid-dorsal line. The ventral and ventrolateral walls of the pharynx have but small masses of cells sparseng distributed over their surfaces. The dorsal wall of the phar- 

ynx has few or no folds and the cells are about equal in height. The lateral and ventral walls are collapsible and show, internally, irregular, longitudinal folds which are intensified by the unequal height of the epithelial cells. (Fig. 8.)

The anterior part of the oesophagus from $V$ to IX is of simple structure; the posterior part from X to XIV is characterized by the presence of the calciferous gland within its walls. In a transverse section through the anterior region, the oesophagus has a circular outline. The epithelium is thrown into short irregular folds, due to the unequal height of the columnar cells, and is in marked contrast to the lining of the dorsal wall of the pharynx which is comparatively straight and in which the cells are of nearIy equal height. The region of the calciferous gland, from $X$ to the posterior part of XIV, is marked externally by an increase in the size of the oesophagus. In $X$ the oesophagus becomes abruptly enlarged, increasing the diameter of the tube two and one half times. The diameter decreases slightIy in XI, and from there diminishes gradually to XIV, where the normal size is regained. (Fig. 2.). There is little or no constriction of the gland between somites. The epithelium of the oesophagus in the region of the glandis thrown into regular longitudinal folds of which there are uniformily $62-64$ in the few specimens examined. They begin in the anterior part of X.(Fig. 3) and extend beyond the middle of XIV. They are regularly distributed over the inner surfaces of the pouches. (Fig. 4) except for a very small portion immediately ventral to the openings of the latter into the lumen of the oesophagus. The folds on the greater part of $X$ are low, toward the posterior part of the somite, where they are increased in height, thein 

distal edges meet and fuse, (Fig. 4), and form a continuous inner epithelial tube. A transverse section thru XI shows the folds as laminae, stretched between the inner epithelial tube and the longitudinal muscle layer of the wall, with blood spaces within and gland cavities between the folds.

The secretory cells of the folds discharge into the gland cavities, which are continuous with the pouches in $X$ and apparentIy communicate. with the lumen of the oesophagus in XIV by slit-like openings through the epithelium.

The outer wall of the oesophagus is cylindrical throughout, and the inner tube, formed by the fusion of the edges of the folds, is cylindrical in XIII and XIV; but in XI and XII it is much compressed; the dorsal and ventral folds are correspondingly low and the dorso-ventral axis reaches from near the dorsal almost to the ventral muscle layers.

The folds are ciliated along their whole course as is also the epithelium of the oesophagus from the posterior part of $X$ to XIV. No cilia could be found anterior to the folds, or on the dorsal or ventral walls of the oesophagus in X (Fig. 4).

The epithelial cells of the oesophageal wall and of the inner tube are columnar, of the folds cuboidal, and the transition from the one to the other is abrupt. (Fig. 7)

In XIII and XIV the lining of the oesophagus is thrown into a number of great ridges.

The crop is in XV and XVI. Its waIls are thick, the columnar epithelium is much folded, and in addition is thrown into large irregular ridges. A very loose network of muscle fibers from the circular layer separate the epithelium and the main part of the 

muscles of the wall.

The gizzard in XVII and XVIII is characterized by very thich compact walls, due to the great development of the circular layer of muscles, the fibers of which are arranged in a series of definite bands encircling the tube. The longitudinal layer of muscles in the gizzard and intestine is somewhat thicker than in the crop. The first indication of the typhlosole is in XX. In XXI it forms a broad low fold which increases in size posteriorly. The columnar epithelial cells of the intestine are wedge shaped, with their broader ends toward the lumen.

\section{CIRCULATORY SYSTEM.}

The dorsal, ventral and sub-reural vessels are present, and extend the whole length of the body. There are five pairs of large commissural vessels in VII - XI, commonly known as hearts, which lie posterior to the nephridia and connect the dorsal and ventral vessels. The small sub-reural vessel lies along the ventral side of the nerve cord embedded in the nerve sheath. There are two lateral vessels, one on either side of the oesophagus, from the anterior region to XII where they join the dorsal vessel. A pair of transverse vessels in $X$ connect the laterals with the dorsal vessel.

According to the investigations of Johnston and Johnson on Lumbricus terrestris; the lateral vessels carry blood to the dorsal vessel. In the posterior part of $\mathrm{V}$ each lateral is formed. by the union of two vessels, one from the dorsal and another from the ventral regions of the pharynx and oesophagus. Two pairs of vessels are in each of somites $V$ - XIV and carry blood from the 

oesophagus to the dorsal vessel, (Johnston and Johnson(I)), but in $\mathrm{X}$ the members of the second pair join the vessel which connects the lateral and the dorsal vessel. Anterior to VII the dorsal vessel decreases in size, but the walls remain thick. Each heart has a dorsal and a ventral valve located near the union with the dorsal and ventral vessels respectively. Also the dorsal vessel has a valve in the plane of each septum.

EXCRETORY SYSTEM.

There is a pair of nephridia in each somite except the first two and the last. They are similar to those of Lumbricus terrestrif Each nephridim occupies parts of two somites. The ciliated nephrostome and the slender short antesseptal part of the tube project from the posterior septum into the cavity of one somite while the remainder including the coiled tubule and the nephridiopore are in the somite following. The nephridial ducts of either side pass from the body cavity between $\underline{b}$ and the lateral muscle band. Their subsequent course from this point depends upon the position of the nephridiopores. If the pore is ventral, the duct passes directly through the circular muscle layer to the exterior, but if it is dorsal, the duct turns dorsad and passes, between the circular and longitudinal muscle layers, to the pore. Because of the thinness of its wall it appears as a mere cleft between the muscle layers. The cells of the distal end of the duct are columnar and appear to be derived from an invagination of the hypodermis.

There are masses of faintly staining cells in the cavities of some of the anterior somites. In paratype $B$ in $V$ - VII ; in paratypes $\mathrm{A}$ and $\mathrm{C}$ in VI - IX. 

MALE REPRODUCTIVE ORGANS.

The spermaries, two pairs of digitate organs, attached to the ventral part of the anterior septa of $X$ and $X I$ lie free in the body cavity, and in line with the large complexly folded ciliated spermiducal funnels which open from the posterior septa of the somites. The two sperm ducts of a side lie close together throughout XII and unite near XII/XII, forming a common duct which lies on the ventral body wall just beneath the peritoneal lining of the body cavity. In $X V$ the duct turns downward into the longitudinal muscle layer of the body wall, where it is surrounded by glandular tissue and through which it takes an oblique outward course to the spermiducàl pore.

The glandular tissue forms a large mass which extends above the level of the floor of the body cavity and encroaches either on XIV or on XVI.

The ducts of the gland cells open to the exterior through the hypodermis in XV. A few open on either XIV or XVI.

The cells of the spermiducal funnel are ciliated and columnar and their nuclei stain deeply. A transverse section through the sperm duct shows ciliated cuboidal cells with oval nuclei arranged with their long axes parallel with the circumference of the duct. (Fig. 13).

There are two pairs of sperm sacs, one in XI and one in XII. The sperm sacs of the latter pair are larger, and each sac is attached to the anterior septum of its somite and opens into the cavity of the somite anterior to it. When fully developed their dorsal extremities meet above the oesophagus. The long axis of the area of the attachment of the sperm sac with the septum is 

oblique to the dorso-ventral axis of the body. The opening through the septum is broad and is at the center of the area of attachment. Each sperm sac consists of lobes of tissue grouped around a central core of loosely arranged connective tissue.

\section{FEMALE REPRODUCTIVE ORGANS.}

The two ovaries in XII are attached by their narrow extremities to the lower posterior face of the anterior septum. Each gradually increases in size from the proximal to the distal end. This increase is coordinated with the increase in the size of the ova which are very small anteriorly and comparatively large posteriorly where they break through the follicles of the ovary and escape into the body cavity.

There are a pair of ciliated oviducal funnels which open from the posterior septum of XIII in direct line with the ovaries. The oviduct passes from the funnels through XIII/XIV, into the body cavity and downward through the body wall to the pair of external openings on XIV immediately dorsal to $\underline{b}$. The walls of the large oviducal funnels are thick, and folded, and ciliated within. Both the funnels and the oviducts have deeply staining columnar epithelial cells.

The oviualsacs, one pair in XIV, are attached to XIII/XIV and open into XIII through large ciliated areas, which are in close proximity or in connection with the oviducal funnels. Each sac is undivided and is capable of holding three or four ova.

No trace of spermathecae can be found in the type specimen or in the paratypes. 

AFFINITIES.

H (B.) zeteki belongs to the genus Helodrilus, and to the subgenus Bimastus. A discussion of the genus and the subgenus will be taken up later in connection with the second species described, which belong also to the same group.

Michaelsen, in his definition of the subgenus places the posterior limit of the clitellum at XXXII/XXXII. In $\underline{H}$. (B.) zeteli it is at XXXVII / XXXVIII, which serves as a character to distinguish the species from all others of the Bimastus type.

H. (B.) zeteki is much larger than the majority of the Bimastus species, and in this respect resembles H. (B.) indicus (Michaelsen) and H. (B.) syriacus (Rosa); but differs from both, in the absence of tubercula pubertatis, as well as in the position of the clitelium.

The position of the clitellum in $\mathrm{H}$. (B.) zeteki makes a satisfactory definition of a subgenus Bimastus still more difficul than before. 



\section{HELODRILUS (BIMASTUS) LONGICINCTUS n. sp.

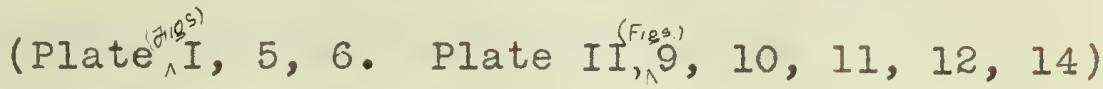

DEFINITION .

The color of the living worm is bright reddish, more pronounced anteriorly. Length $72-92 \mathrm{~mm}$. Maximum diameter $3 \frac{1}{2} \mathrm{~mm}$. at the clitellum. Somites 72 - 114. Prostomium epilobic $1 / 2-2 / 3$. Setae closely paired anterior to the clitellum aa: $\underline{a b}$ : $\underline{b c}: \underline{c d}: \underline{d d}$ : $=155: 15: 115: 12: 440: \underline{d d}=$ about $\frac{1}{2}$ the circumference. First dorsal pore V/VI. Clitellum XXIII - XXXII ( $=10$ somites); incomplete ventrally. Tubercula pubertatis lacking. Spermiducal pores on XV, opening on an elevated glandular area which encroaches slightly on

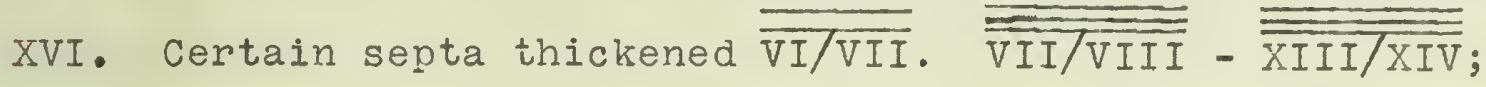

$\overline{\overline{X I V} / X V}$. Sperm sacs, two pairs in $X$ and XI. Spermathecae lacking. The specimens, on which the description is based are found in Urbana, Illinois, in the soil of lawns and parkings. 

EXTERNAI CHARACTERS.

The color of the living worm is bright reddish, more pronounced on the dorsal surface of a few of the anterior somites.

The length of extended specimens is $72-92 \mathrm{~mm}$. The maximum diameter of every worm examined is $3 \frac{1}{2} \mathrm{~mm}$., measured through the clitellum. The different regions of the remainder of the body are $1 \frac{1}{2}-2 \frac{1}{2} \mathrm{~mm}$. in diameter, the variation being due in part to unequal contraction. Generally the preclitellar region has the greatest diameter which is about 2 or $2 \frac{1}{2} \mathrm{~mm}$.

Each somite is indistinctly annulated in the middle line, and the anterior half of the somite appears less opaque than the posterior half.

The number of somites is 96 - 109. Those of the anterior end of the body are not longer than the ones posterior to the clitelium.

The prostomium is broadly epilobic, $1 / 2-2 / 3$.

The setae are closely paired and are arranged in nearly parallel rows, but the rows are not straight because the setae of the pairs are not every where equi-distant. The variation rarely equals one-fourth the average distance between the setae, $\underline{a a}$ : $\underline{a b}$ : $\underline{b c}:$ cd: $\underline{d d}=155: 15: 115: 12: 440 ; \underline{d d}=$ about one-half the circumference In the posterior region, the same relations of setae are maintained, with the exception of one specimen in which bc is relatively greater and $\mathrm{dd}$ is less than one-half the circumference.

The first dorsal pore is in V/VI.

The clitellum on XXIII - XXXII ( $=10$ somites) is distinctly set off from the rest of the body by its yellowish color and its greater diameter. It is saddle-shaped. The ventral margins from 

XXIV - XXXI are straight and converge posteriorly. The width of the space between them at the anterior andt the posterior ends differ from $\frac{1}{2}$ to $\frac{3}{4} \mathrm{~mm}$. In XXVII - XXXI the ventral margins reach $\underline{b}$ which is the ventral limit of the clitellum. No traces of tubercula pubertatis are recognizable.

The mouth is on the ventral surface of I, limited by the prostomium dorsally.

The anus is a vertical slit surrounded by the last somite. A pair of spermiducal pores open through transverse slitlike apertures, which are surrounded by raised glandular tissue, forming a pair of comparatively large protuberances, one on either side of $X V$ on the latero-ventral surfaces. These protuberances are prominent in the preserved specimens partly because of their yellowish color. They extend as far ventrally as $\underline{b}$ and encroach posteriorly on XVI. Their width is about one half the interval between $\underline{b}$ and $\underline{c}$. The pores are very near $\underline{b}$ and in the seta line of the somite.

The oviducal pores, on XIV, immediately dorsal to $\underline{b}$, are small oval and inconspicuous.

Approximately one half of the nephridiopores open dorsally the others ventrally. The dorsal nephridiopores show less tendency to form straight rows than do the ventral ones. On the average the pores of the dorsal row are nearer to seta line $\underline{d}$ than to the mid-dorsal line. The ventral row is slightly dorsal to seta line b. Fig. 9 and 10 show the position of the dorsal and the ventral nephridiopores. The pores are in the anterior one fourth of the somite. 

INTERNAL CHARACTERS.

CENTRAL NERVOUS SYSTEM.

The brain is in III on the dorsal surface of the pharynx. Circum-oesophageal connectives pass from it to the sub-oesophageal ganglion in IV. The nerve cord extends, posteriorly, from the suboesophageal ganglion. A pair of nerves are given off from the brain, and two pairs from the circum-oesophageal connectives, one of which passes to the pharynx, the other to the ventral body wall. The nerve cord has three pairs of branches in each somite. The first and third are each one fourth the length of the somite from the anterior and posterior septa respectively. The second pair is very near the third. The first pair is from the latero-ventral margins of the cord (Fig. 11); the second and third from the middle of the lateral surfaces (Fig. 12).

ALIMENTARY CANAL.

The wall of the alimentary canal includes an inner circular and an outer longitudinal layer of muscles. Both layers are much reduced in the buccal region.

The inner epithilial lining of the buccal cavity shows narrow ridges which are comparatively high and nearly in contact. The epithilial cells which form the ridges are columnar, many of them are very narrow at their bases and broad at their extremities.

The pharynx in III and IV is covered with a mass of muscular and glandular tissue which nearly fills the entire cavities of the somites. The latter is distributed, over the surface of the muscles as small groups of cells, except on the posterior part of the dorsal surface where the cells form a large mass which covers 

the muscles completely and projects posteriorly to IV/V. The dorsal wall of the pharynx lies in a nearly frontal plane with few folds. Its columnar epithelial cells are high and stain deeply. The ventral and lateral surfaces of the pharynx have large irregular folds, due to the unequal heights of the epithelial cells. Cilia cover the dorsal and ventral surfaces of the pharyngeal cavity.

The anterior part of the oesophagus from V - IX is compressed so that the width in the dorso-ventral plane is considerably greater than in the frontal plane. (Fig. 2$)$. The epithelial lining is thrown into ridges which are generally short and are lower than those of the ventral and lateral walls of the pharynx.

The single calciferous gland extends from $X$ to $\frac{7}{2}$ XIV. The dilatation of the gland in $\mathrm{X}$ is abrupt and the diameter is about twice as great as in IX. From $X$ to XIV there is a gradual diminution in the size of the tube (Fig. 2). The gland consists of from 58 - 60 longitudinal folds of the epithelium of the oesophagus. Each fold begins in the anterior part of $X$ and extends into XIV. The inner edges of the folds fuse in the posterior part of $\mathrm{X}$ and form an inner tube which extends to about $\frac{1}{2} \mathrm{XIV}$; and which is much compressed in $\frac{1}{2} X$ to XII. (Fig. 5). Blood is contained in the sinuses within the folds. (Fig. 5. bl. sin. f.). The gland cavities between the folds (Fig. 5, gl. c.) are continuous with the Iumen of the oesophagus in $\mathrm{X}$. There is communication between gland cavities and oesophageal lumen in XIV, through slit-iike apertures in the epithelium of the inner tube. (Fig. 6.)

In XIII and XIV the epithelial lining of the oesophagus is thrown into a few high longitudinal ridges. The muscular wall is 

fairly well developed, except from lhe posterior part of $X$ to the anterior part of XIII, where it is very thin.

The crop is in XV and XVI. Its epithelial lining is narrowly separated from the longitudinal and circular muscle layers by a net-work of fibers derived from the latter. As in the oesophagus the epithelial cells are of unequal height and the lining is thrown into short low folds.

The gizzard, in XVII - XVIII, has a very thick wall. The longitudinal muscle layer is about as thick as in the crop, but the circular layer has increased greatly. The epithelium forms low, narrow folds which are nearly uniform in size.

In the intestine, the circular muscle layer is better develop ed than the longitudinal layer.

The typhlosole begins in XX and increases in size abruptly in XXX - XXXI.

CIRCULATORY SYSTEM.

The circulatory system has not been studied in detail.

A pair of hearts in each of somites VII - XI connect the dorsal and ventral vessels. The hearts in XI are much smaller than the others and this condition is found in each specimen studied. Each heart has a dorsal and a ventral valve. (Fig. @. - d. vlv h, v. v'lv. h.); also the dorsal vessel has a valve in the plane of each septum. The valves in VIII - $\mathrm{X}$ are not well developed. The lateral vessels lic one on either side of the oesophagus, and join the dorsal vessel in XII. A pair of transverse vessels in $\mathrm{X}$ connect the laterals with the dorsal. Dorsal intestinal vessels carry blood from the alimentary canal to the dorsal vessel 

Fig. 5. The sub-reural vessel is embedded in the sheath which surrounds the nerve cord. (Fig. 12). Lateral-neural vessels were not found in any of the sections.

EXCRETORY SYSTEM.

There are paired nephridia in each somite except I and II. No otvious differences in structure or relation to other organs have been found between these organs of this species and those of Helodrilus zeteki.

MALE REPRODUCTIVE ORGANS.

There are two pairs of spermaries in $\mathrm{X}$ and $\mathrm{XI}$. They are attached to the anterior septa of their respective somites. Large ciliated spermiducal funnels open on the posterior septa of $X$ and XI. The sperm ducts lic underneath the peritoneal lining of the body cavity. In $X V$, they pass obliquely to the pore through the muscle layers and the glandular tissue which is commonly associatef ed with the distal portion of the sperm duct. This glandular tissue forms a pair of protuberances on the ventral floor of the body cavity in XV which encroach on XVI. The ducts of the gland cells apparently do not communicate with the sperm ducts.

There are two pairs of sperm sacs, one in XI and the other in XII. These sacs are attached to the anterior septa of their respective somites and open into the cavities of $X$ and XI. The long axis of the line of attachment of each sperm sac with the septum is somewhat oblique to the dorso-ventral axis of the body.

FEMALE REPRODUCTIVE ORGANS.

There is a pair of ovaries attached to the anterior septum 

of XII. Each ovary is narrow at its proximal and broad at its distal end. The large ciliated oviaucal funnels open on the posterior septum of XIII. Each oviduct passes diagonally through the cavity of XIV to the oviducal pore near $\underline{b}$ on the same somite. A transverse section through the oviduct shows a very thin outer layer of muscle fibers and connective tissue, and internally a ciliated and folded epithelial lining. (Fig. 14.) The cells of the epithelium stain deeply.

There is a pair of ovisacs in XIV, each of which open into XIII, and in other respects resemble those of Lumbricus.

AFFINITIES.

This species is of the Bimastus type.

The position of the clitellum on XXIII - XXXII ( 10 somites agrees closely with that of $H_{\text {. ( }}$ (B.) beddardi (Mich) and $H_{\text {. (B.) }}$ eiseni (Levins). In the former the clitellum is on XXIV, XXV XXXI, $\frac{1}{2}$ XXXII ( $=7 \frac{1}{2}-8$ somites); in the latter on XXIV, XXV - XXXII $(=8-9$ somites $)$

H. (B.) Iongicinctus differs from $H_{\text {. ( }}$ (B) eiseni in the position, and in the extent of the clitellum; in the arrangement of the setae and in the character of the prostomium which in $\mathrm{H} .(\mathrm{B})$ longicinctus is epilobic, and in $\underline{\mathrm{H} .(\mathrm{B})}$ eiseni, tanylobic.

H.(B) longicinctus resembles H.(B) parvus (Eisen) in the arrangement of setae but differs from it in length of clitelium and in the absence of tubercula pubertatis.

\section{H. (B) longicinctus is closely related to $\mathrm{H}$. (B) beddardi} (Mich). However there are a number of distinct differences. The following table is a comparison of certain characters in $H$. (B) 

longicinctus with the same characters in $\underline{H .(B)}$ beddardi as given by Michaelsen $(2,3)$.

H. (B) longicinctus

Setae $\underline{\mathrm{cd}}=3 / 4 \underline{\mathrm{ab}} ; \underline{\mathrm{b}} \mathrm{c}=3 / 4 \underline{\mathrm{a} a} ; \underline{\mathrm{dd}}=$ $1 / 2$ circumference.

Clitellum XXIII - XXXII

Tubercula

Pubertatis. No trace

Glandular Glandular tissue surtissue in rounding spermiducal XV

Septa

\section{$\mathrm{VII/VIII} \mathrm{-} \mathrm{XIII/XIV}$}

considerably thickened pore well developed.
H. (B.) beddardi (Mich). $\underline{c d}=3 / 4$ ab; $\underline{b c}$ little less than $\underline{\text { aa }} ; \mathrm{dd}=\mathrm{l} / 2$ circumferenow. XXIV, XXV-XXXI, I/2 XXXII. $X X V$ or XXVI - XXX not distinct.

Glandular tissue surrounding spermiducal pore but slightly developed.

All very thin.

Two specimens from Florida, presumably H.(B.) beddardi, from the collections of Professor Smith, show all the septa unusualIy thin and delicate. In this respect, the contrast between this form and $\mathrm{H}_{\text {.(B.) }}$ longicinctus, in which certain septa are decidedy thick, is very marked. Further comparisons show that the hearts

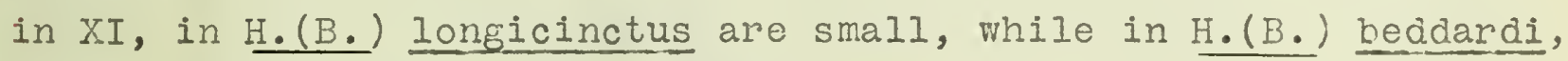
all of the hearts are of the same size.

Michaelsen (4) reports a specimen from Tibet which has the clitellum on XXIII - XXXII and which he places with H.(B.) beddardi. No mention is made however of other characters of use in the deternination of species. In the absence of tubercula pubertatis, there seems some question as to which species this specimen more closely resembles. 



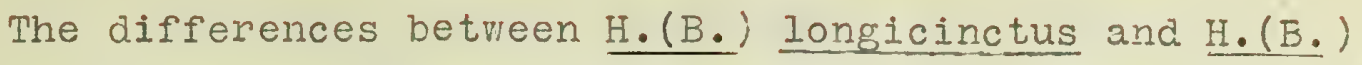
beddardi in the absence of intergrading forms are too great to warrant their treatment as one species. 

GENUS HELODRILUS. HOFFMEISTER EM. MICHAELSEN

In a recent paper 1910, Michaelsen (4) unites Eiseniella, Eisena, and Helodrilus, and recognizes only three genera in Lumbricidae, namely, Helodrilus, Octolasium and Lumbricus.

Helodrilus is characterized by the absence of a sac enclosing the spermaries and spermiducal funnels, and by the prostomium being usually epilobic, seldom tanylobic or prowilobic.

\section{SUBGENUS BIMASTUS H. F. MOORE.}

H. F. Moore in 1893 (5) published a preliminary account of a new American genus, Bimastus, with a new species palustris as the type. In 1900 Michaelsen (4.) made Bimastus a subgenus under Helodrilus.

The definition by Michaelsen ( 3 ) is as follows: Clitellum not posterior to XXXII/XXXII, but seldom reaching as far. Tubercula pubertatis laclring, or if present not sharply defined. Two pairs of sperm sacs in XI and XII attached to X/XI and XI/XI. Spermathecae lacking. Generally small forms with reddish pigment. The discovery of $\mathrm{H} .\left(\mathrm{B}_{.}\right)$zoteki necessitates the omission of the posterior limit of the clitellum as a character of the subgenus. 

LITERATURE CITED.

Johnston, J. B. and Johnson, Sarah W.

1. '02. The Course of the Blood Flow in Lumbricus. Am. Nat. $36: 317-328$.

Michaelsen, W.

2. '94. Die Regenwurm - Faunka von Florida and Georgia. Zool. Jahrb. Abth. f. Syst. 8: 177 - 194.

3. 'Oo. Oligochaeta. Das Tierreich, 10 Lief, XXIX + 575 pp., 13 fig. Berlin.

4. 10. Zur Kenntnis der Lumbriciden und ihrer Verbreitung. Ann. Mus. Zool. Acad. Imp. Sc., St. Petersb. 15:1-74

Moore, H. F.

5. '93. Preliminary Account of a New Genus of Oligochaeta. Z0o1. Anz. 16: $333-334$. 

EXPLANATION OF PLATES.

ABBREVIATIONS.

bl. sin, blood sinus in wall of oesophagus.

bl, sin. f., " " " cavity of fold of calciferous gland.

bl. v., "vessel.

br. s'b. v., branch of sub-neural vessel.

cil., cilia.

circ, m., circular muscle layer.

c'l. c.gl., cells of fold of calciferous gland.

d.bl. v., dorsal blood vessel.

d. i. v., dorsal intestinal vessel.

d. np. po.," nephridiopore.

d. v'Iv.h., " valve of heart.

d. w. oes., " wall of oesophagus.

d. w. phar., " "pharynz.

ep. epithelium

ep. c. gl., epithelium of calciferous gland.

ep. oes., " " oesophageas wall.

f. fold of calciferous gland.

gl. cav., gland cavity.

gl. t., glandular tissue of pharynz.

h., heart.

hyp., hypodermis.

in. ep., inner epithelial tube.

1. bI. V., lateral blood vessel.

long. m., longitudinal muscle layer.

Ium., Iumen of oesophagus.

i:w. f., low folds of calciferous gland. 

1.w. phar., lateral wall of pharynx.

m. n'p. d., muscular part of nephridial duct.

m. W. phar., muscles of pharyngeal wall.

n., nerve.

n.c., nerve cord.

n'p. d., nephridial duct.

oes., oesophagus.

op'. gl. cav., opening of gland cavity into lumen of oesophagus.

p., peritoneum.

p'ch. c. gl., pouch of the calciferous gland of the oesophagus.

pr. ep., primary epithelium.

s'b. n., sub-neural vessel.

set. a., seta a

set. b., seta $b$

set. c., seta $c$

set. d., seta d

sp. d., sperm duct.

spr. spermary.

sp. s., sperm sac.

v. bl. v., ventral blood vessel.

v. n'p. po., ventral nephridiopore.

v. v'lv. h., ventral valve of heart.

v. W. oes., ventral wall of oesophagus.

v. w. phar., ventral wall of pharynx.

\section{PIATE I.}

Figs. 1, 3, 4, 7. Helodrilus (Bimastus) zeteki.

Figs. 5,6 .

Helodrilus (Bimastus) longicinctus. 

Fig. 1. Prostomium.

Fig. 2. Diagrammatic frontal section through oesophagus X - XIV, showing calciferous gland.

Fig. 3. Transverse section through oesophagus Plane A. Fig. 2., showing beginning of folds on wall of pouch of calciferous gland.

Fig. 4. Transverse section through oesophagus, Plane B. Fig. 2., showing the union of folds of calciferous gland, to form the inner epithelial tube of the oesophagus.

Fig. 5. Transverse section through oesophagus Plane C. Fig. 2. Fig. 6. Transverse section through oesophagus Plane D. Fig. 2., showing communication between gland cavities of calciferous gland and lumen of oesophagus.

Fig. 7. Part of a transverse section through oesophagus in the posterior part of $X_{\text {. }}$, showing transition from epithelium of oesophageal wall (ep, oes) to that of calciferous gland (ep.c. gl.)

\section{PLATE II.}

Figs. 8, 13. - Helodrilus (Bimastus) zeteki.

Figs. 9-12, 14. - Helodrilus (Bimastus) longicinctus.

Fig. 8. Transverse section through pharynx in IV.

Fig. 9. Transverse section through VIII showing position of dorsal nephridiopore.

Fig. 10. Transverse section (slightly oblique) through X and XI, showing position of ventral nephridiopore.

Fig. 11. Transverse section through nerve cord, showing origin of first pair of nerves of $\mathrm{XX}$. 

Fig. 12. Transverse section through nerve cord, showing origin of one member of the third pair of nerves of $\mathrm{X}$.

Fig. 13. Transverse section through sperm duct, showing relation to surrounding parts.

Fig. 14. Transverse section through oviduct. 



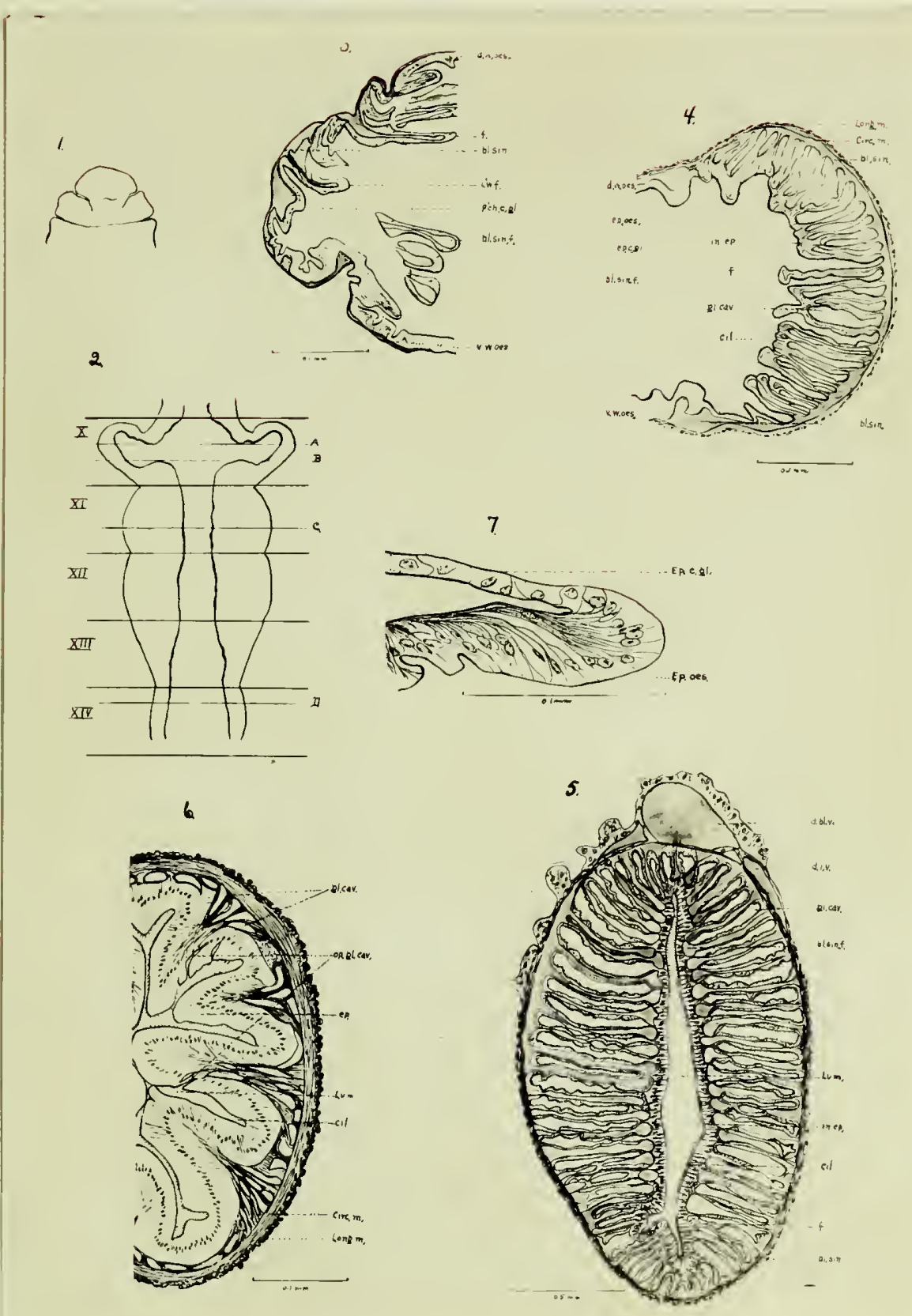




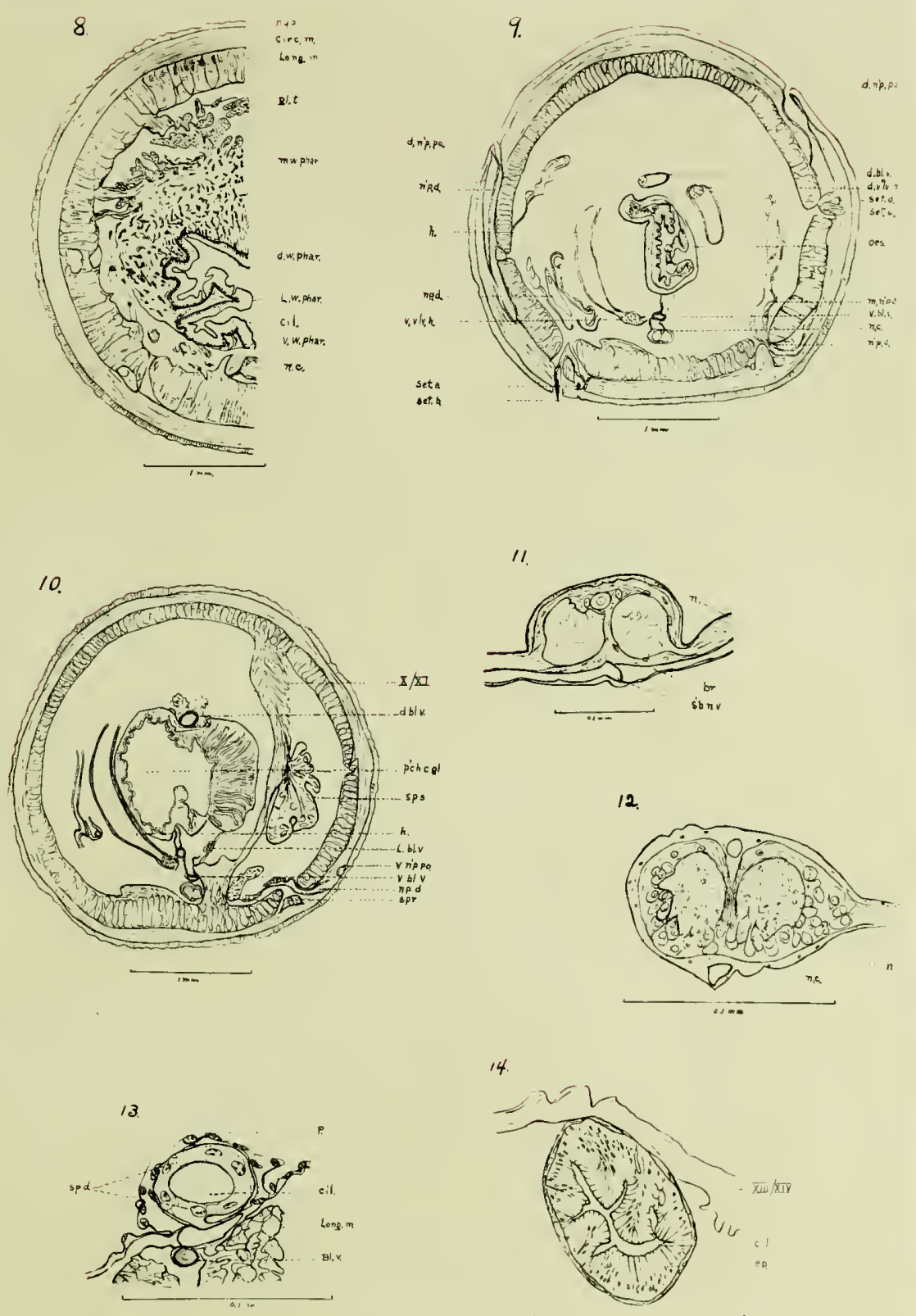



$$
10 / 21 / 39
$$

UNIVERSITY OF ILLINOIS LIBRARY URBAN, ILLINOIS

The book noted below, drawn out by you for use in the reference room, should not have been taken from the library. Kindly return it at once. At is subject to a fine of $25 \mathrm{c}$ a day.

$$
\begin{array}{ll}
1914 & 1915 \\
244 & 1364
\end{array}
$$
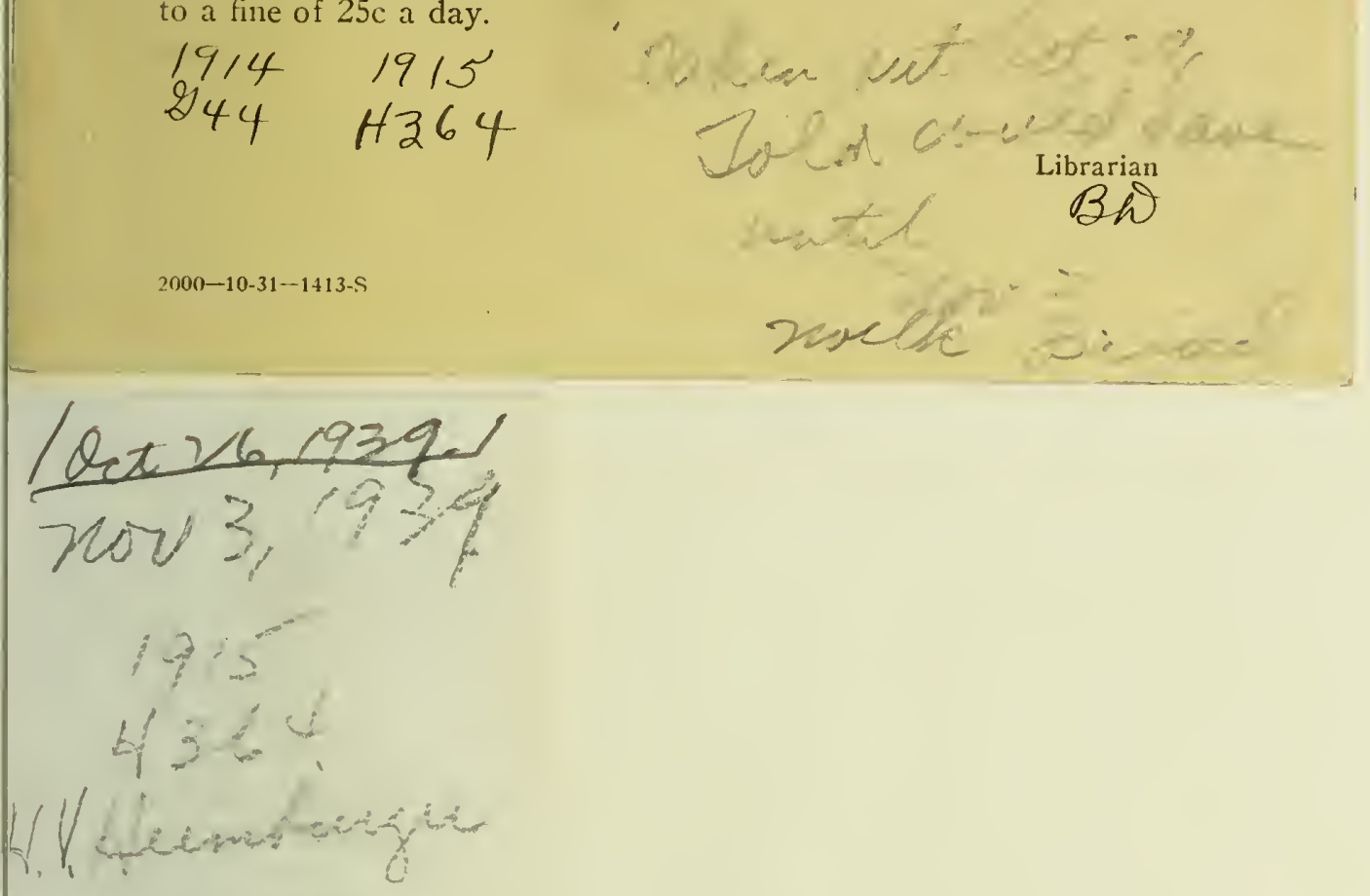

Butene or

Thana

and 

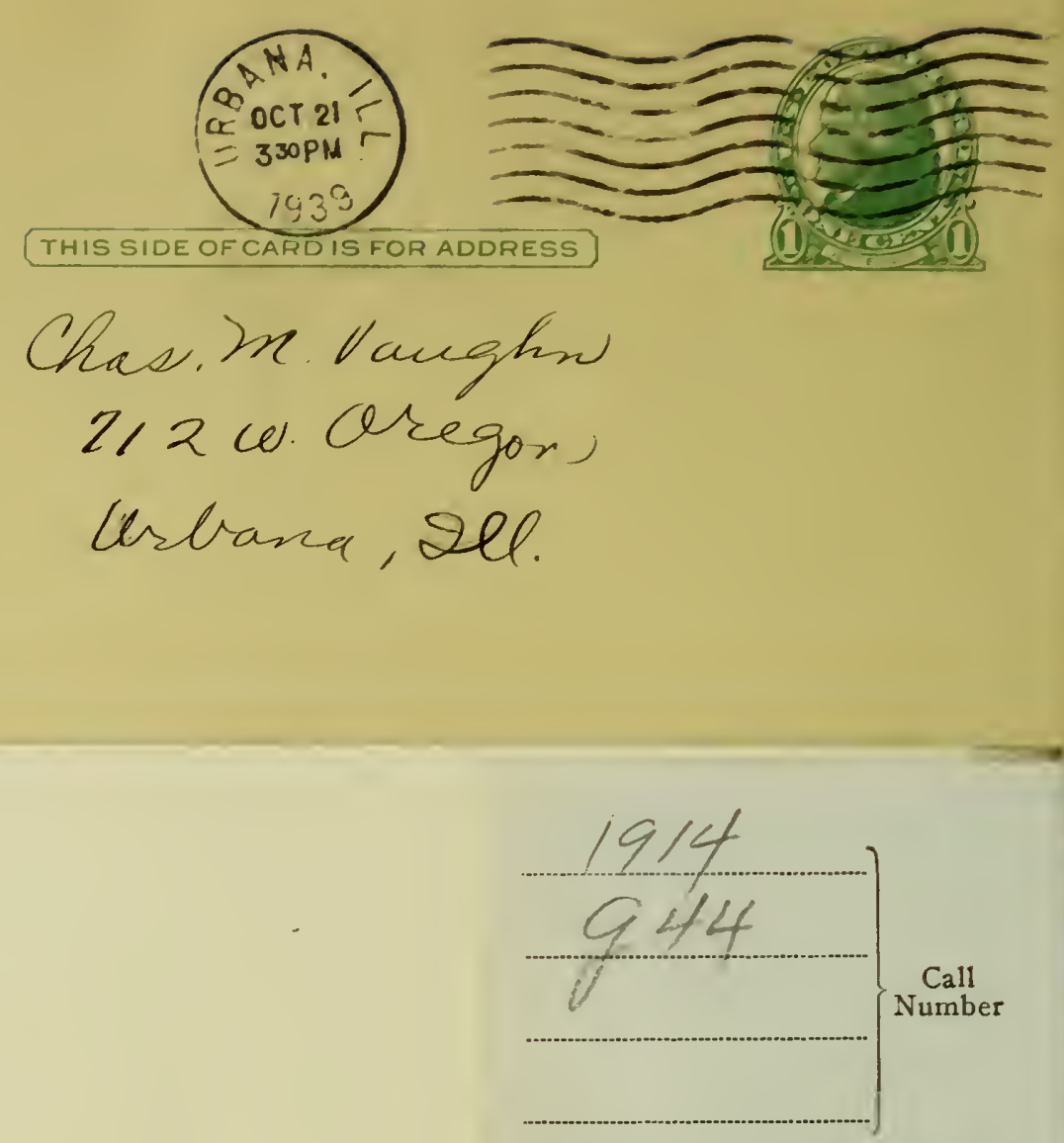

Overdue books are subject to a fine of 2 cents a day. Author.

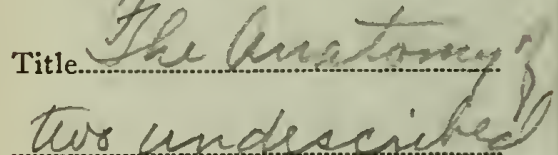
Alevin tolidine finley $y=$ Name 19 Identification Identification
number....................... Address -1$)$ Univ. of Ill. Lib. Call Slip 


$$
\text { - }
$$


